\title{
A STUDY OF REQUEST STRATEGIES USED BY EFL BATURAJA UNIVERSITY
}

\author{
Mila Arizah ${ }^{1}$, Merie Agustiani' ${ }^{2}$ Karina D.K ${ }^{3}$ \\ milaarizah1984@gmail.com; merieagustiani@gmail.com; karinadwik16@gmail.com
}

\section{Baturaja University}

\begin{abstract}
The problem in this studyis about the request strategies used by ESL Baturaja University Students. The aim of this study was to determine the most common request strategies used by EFL Baturaja University students. In this analysis, the descriptive approach was used as the research methodology. The sample of this study was taken through cluster random sampling and they were taken from English education that were taken from English students of English education study program in academic 2020/2021. For collecting the data writer used a discourse completion test (DCT). The result was as much as $16.55 \%$ student response used direct strategies, as many as $81.81 \%$ student responses used conventionally indirect, and as many as $1.62 \%$ student responses used Non-conventionally. It means that the dominant request strategies used by EFL was the conventionally indirect.
\end{abstract}

Key words: Pragmatic, Request strategies, Discourse completion test (DCT)

\begin{abstract}
Abstrak: Masalah dalam penelitian ini adalah tentang strategi permintaan yang digunakan oleh Mahasiswa pendidikan Bahasa Inggris Universitas Baturaja. Tujuan dari penelitian ini untuk mengetahui strategi permintaan apa yang dominan digunakan oleh mahasiswa Pendidikan Bahasa Inggris Universitas Baturaja. Metodologi penelitian yang digunakan dalam penelitian ini adalah metode deskriptif. Populasi penelitian adalah 80 siswa dan sampel berjumlah 22 orang yang diambil secara cluster random sampling yang dari program Studi Pendidikan Bahasa Inggris tahun ajaran 2020/202I sehingga diperoleh 16.55\% siswa menggunakan direct strategies, sebanyak $81.81 \%$ siswa menggunakan conventionally indirect, dan sebanyak $1.62 \%$ siswa menggunakan Non-conventionally. Artinya, strategi permintaan yang dominan digunakan oleh mahasiswa Pendidikan Bahasa Inggrisa dalah conventionally indirect.
\end{abstract}

Kata kunci: Pragmatis, Strategi permintaan, Tes penyelesaian wacana (DCT)

\section{INTRODUCTION}

Language plays an important role in our everyday interactions with others and in sharing our feelings. According to Amberg and Vause (2000, p. I), language is first and foremost a form of communication, and communication almost always occurs in a social context. This is why understanding is essential for successful communication. It means that language is a vital tool for communication in our everyday life and that

${ }^{1,2,3)}$ Dosen Universitas Baturaja 
language is one of those tools. Language is a means of communication. By using language people can express ideas, thought, opinions and their minds. Language is the most important medium of communication in the world since it is difficult for people to communicate with one another and carry out their everyday life without using language.

English is a widely spoken language in many parts of the world. This dialect is widely spoken throughout the world. As a result, English has been designated as a foreign language by the Indonesian government. Furthermore, it is the first foreign language taught in Indonesian junior high, senior high, and university levels as a compulsory subject. In learning language, there are four skills should be mastered by students, such as listening, speaking, reading andwriting. During the teaching and learning process in the classroom, the teacher can use these four skills. Reading and listening are reactive abilities, while speaking and writing are aggressive abilities (harmer, 2001).

Language can be learned in a variety of ways. The realistic approach is one of the techniques used in analysis. The analysis of meanings as expressed by a speaker (or writer) and interpreted by a listener is known as pragmatics. As a result, it is more concerned with determining what people mean by their utterances than with determining what the words or phrases in such utterances mean in and of themselves (Yule, 1996, p. 3).

People not only create utterances containing grammatical structures and words in order to express themselves, but they also perform actions through those utterances, which are referred to as speech acts. Speech actions are utterances that serve a communication purpose. When giving an order, query, appeal, or advice in real-life experiences, the speech act may be used. Speakers also instruct listeners to understand the role or communicative intent of the utterances they create and to respond appropriately. They are often aided by the circumstances surrounding the utterance or speech act (Yule, 1999, p. 47).

Under the study of speech act production, request has been the most important act studied in interlanguage pragmatics. Although request is the most common of speech act used by people to ask someone doing something in daily basis, it is not easily done by L2 learners. A number of study has examined how learners produced request expressions in second language and they have shown that learners opted for different request strategies. As reported the proficiency increase learners to develop 
request strategies from lessdirect level to a more direct level.

Related to communication, request appears as one of speech acts which learners must be aware of. The reason is that its successfulness or failure may determine the positive or negative outcomes. Achiba (2003, p.3) conveyed that request is usefuland occur frequently, especially among learners of a new language. In Indonesia, it can be proven that request is regularly occur in daily communication in EFL classroom.

Trosborg (1995, p. 159) believed that request is an illocutionary act whereby a speaker conveys to hearer that he/ she wants the hearer to perform an act which is for the benefit of the speaker and, sometimes, for the hearer. There are four classifications of request strategies proposed by Troshnrg (1995), those are: indirect request, hearer oriented condition, speaker- oriented conditions, direct request.

Based on the explanation above, the aim of this study is to determine what strategy requests was dominant in used by EFL students. The research subjects was students of the English study program who will be selected as the sample of this study. Research is limited to find out the dominant demand strategy used by EFL students. The writer was interested in conducting a study entitled
"Study of Request Strategies used by EFL Students of Baturaja University”.

\section{a. Concept of Pragmatics}

Pragmatics is a branch of linguistics that studies how people use words to convey meaning. There are a few pragmatic implications. Definition, sense, and communication are three broad and dynamic concepts that are outlined in pragmatics..

Pragmatics is a branch of linguistics that studies how people interact in different cultures (Nadar, F.X, 2009). Many linguists, for example, have contributed to the understanding of pragmatic studies, including Parera (2001) describes that pragmatics is the study of how people use language in conversation, as well as the relationship between words, meaning, circumstance, and time.

The definition put forward by Parera details can be seen in the following: (a) How to interpret and use of speech relies on real world knowledge. (b) How the speaker uses and understands narrative acts; (c) How sentence structure is influenced by the relationship between the speaker or speakers and listener orspeaker. 


\section{b. Concept of Speech Act}

The speech act is one of the most critical aspects of pragmatics in this research. Yule (2006) writes, “A speech act is usually defined as action by utterances". It means that utterances are made up of more than just grammatical structures and words; they are also made up of actions. The actions are influenced by what people say in their utterances.

An utterance with communication intent is referred to as a speech act. We perform speech acts when we apologize, greet, order, lament, invite, praise, or deny. "People not only construct utterances containing grammatical structures and sentences in order to express themselves; they also perform actions through those utterances," Yule writes (2006). It means that after the speaker has said something, the listener must immediately take action.

\section{c. Concept of RequestStrategies}

By making declarations of desire, the speaker may ask others to do something in a respectful or formal manner. A request is an act that expresses the speaker's expectations of the listener regarding a good prospective action verbally or non-verbally (Blum-Kulka in
Ayuningtias, 2012) Asking can be interpreted as listeners can refuse to obey (Lyons in Ayuningtias, 2012). Speech act request as a polite word or sentence to ask.

There are four conditions for making a requestpolitely, namely I) the speaker wants the action to be done; 2) the speaker believes listeners can take action; 3) the speaker believes that the listener wants to do action; The first oxalate request condition is called speaker-based, the third and fourth are called listener-based, and the first oxalate request condition is called speaker-based (Khaliba, 2014)

In the speech act, one of the topics of discussion is request. The speaker assumes that the hearer is capable of performing an action by initiating a request. To ask someone to do something is to use the word "ask." A request strategy, according to the CCSARP (Blum-Kulka in Achiba, 2003), is characterized as "the obligatory choice of the level of directness by which the request is realized." The degree to which the speaker's illocutionary motive is evident from the lucotion is referred to as directness. 
Bum-ThenryKulka's separated demands into two categories: direct and indirect. Direct strategy (D) consist of five types, mood derivable, explicit performative, hedge performative, obligation statement, and want statement. Indirect strategy is classified into two categories: conventionally indirect (CI) and non-conventionally indirect (NCI), with the conventionally indirect (CI) strategy having two types: suggestory formulae and question formulae, and the non-conventionally indirect (NCI) strategy having two types: heavy hint and mild hint.

\section{METHOD}

This study was descriptive qualitative. According to Stewart in Proserbs (20II, p.2I), descriptive qualitative analysis is a method of analyzing an issue based on the data quality. As a consequence, the number of participants is less important than the quality of the results. They put on a display. And the sample for this analysis was 22 students from the 5th (fifth) semester.

In this study analyzed the dominant strategic requests by EFL Baturaja University. The discourse was used as a data collection tool in this qualitative analysis completion test (DCT).
Data collection, data reduction, and research emphasis were used to characterize the data analysis activities. They go on to say that the data reduction or data condensation process can be done in a variety of ways, including collection, description, or paraphrase of a larger pattern.

This study continued the research by selecting and simplifying the data they are presentation, drawing conclusions and verification.

\section{RESULT AND DISCUSSION}

Based on the results of 22 students, students respond using direct strategies if presented will be calculated $=51 / 308 \times 100=$ $16.55 \%$. Students respond that using conventionally indirectly if given will be calculated $=252 / 308 \times 100 \%=81.81 \%$. And students respond using non-conventional indirect if the percentage will be calculated $=$ $5 / 308 \times 100 \%=1.62 \%$. It was concluded that the results in the discourse completion test (DCT) regarding the strategy requests used by students. So the result was as much as $16.55 \%$ student responses used direct strategies, as many as $81.81 \%$ student responses used conventionally indirect, and as many as $1.62 \%$ student responses used Non-conventionally indirect. Therefore, the responses from students of English education 
study program in request strategies was mostly using conventionally indirect.

It found that the fifth semester student data collection using three strategic requests. Namely direct strategy, with response expression; "I want", borrow your ", help me", etc. conventionally indirect with response expression; "Excuse me", "Can I/you", "Could I/ you", "May I", "Please". And also used $\mathrm{N}$ on conventionally indirect strategies. Secondly, from the research results, it shows that the request strategies used by students used conventional indirect strategies. Because it is used more often in a day and the conventional strategy is not directly a kind of polite request.

It means that, from the three strategies, the dominant request strategies used by EFL Baturaja University used conventionally indirect strategies. We observed and assess based on Indonesian culture that tends touse politeness strategies. Jeanyke \& Tanto (2018) stated that people in Indonesia are aware of the differences in social power and distance relation. The majority of the data also shows that Indonesians are more likely to refrain from specifically expressing their demands in order to preserve good relationships with others while also reducing the risk of injury to their face on when communicating with other people.

\section{IV.CONCLUSION}

Based on the finding of this study, it found that, the fifth semester student using three strategic requests. Namely direct strategy, Conventionally indirect And also use Non-conventionally indirect strategies. This study explored the request strategies. When requesting someone in 14 situations, the EFL learners tended to use ability/willingness/permission.

Most students applied politeness device "please" even though they requested to someone who was very close. They employed some politeness devices above in their request to soften their requests. In using a politeness device "please", the respondents tended to produce requests that could be rate too life, especially when they requested to a friend.

After conducting the research and analyzing the data, the writer concluded that the dominant request strategies used by EFL Baturaja University student used conventionally indirect strategies. 


\section{REFERENCES}

Achiba,M.(2003).Learning to Request in a Second Language (A Study of Child Interlanguage Pragmatics). Canada: Multilingual Matters Ltd.

Al-marrani, Y. M. \& Sazalie, B. A. (2010). Polite request strategies as produced by Yemeni EFL learners. Languagein India.

Arikunto, S. (2010). Prosedur Penelitian: Pendekatan suatu praktek.

BlumKulka, S. 1989. Playing it safe: The role of conventionality in indirectness. In Blum Kulka,S., House, J. and Kasper, G.(eds). Cross-cultural pragmatics: Requests and apologies. Norwood: Ablex Publishin.

Cohenet al. (2007). Research Methods in Education. London and New York.

Creswell, W. J. (2012). Educational research: planning, conducting, and evaluating quantitative and qualitative research (4th ed.). Boston: Pearson Education. Retrieved from: http://basu.nahad.ir/uploads/creswell.pdf

Daskalovska, N. Ivanovska, B. Kusevska, M. \& Ulanska, T. (2016). The Use of Request Strategies by EFL Learners. International Conference on Teaching and Learning English as an Additional Language.

Dong, X. (2009). Requests in Academic Setting In English, Russian, and Chinese.

Unpublished dissertation: The Ohio University.

Freankel, J. R., \& Wallen,E.N. (2008). How to design and evaluation research in education.

San Fransisco State University: Me Grow Hill.

Graha Ilmu. Trosborg, A. (1994). Interlanguage Pragmatics request, complaint, and apologies. Berlin: Moutonde Gruyter.

Griffths, P. (2006). An Introduction to English Semantics and Pragmatics. Edinburg: Edinburg University Press Ltd

Jakarta: Rineka Cipta. Arikunto, S. (2017). Pengembangan instrument penelitian suatu pedekatan praktik. Jakarta: Rineka Cipta.

Jalilifar, A. (2009). Request Strategies: Cross-Sectional Study of Iranian EFL Learners and Australian Native Speakers. English Language Teaching. Retrieved from: www.ccsenet.org/journal.html

Jeanyke.\&Tanto,T.(2018). Request Strategies in Indonesian: An Analysis of Politeness Phenomenain Text Messages. Journal of Language and Literature. Vol.18. No. 2. 
Kreidler, Carol, J. (1998). Visual Aids For Teaching English To Speakers of.

Mc.Millan, James, H. (2010). Educational research fundamentals for the consumer. Virginia Common wealth University: Harper Collins Publishers.

Memarian, P. (2012). The use of request strategies in English by Iranian graduate students:

A case study. Thesis. Eastern Mediterranean.

Miles and Huberman. (2014). Analisis Data Kualitatif. Jakarta: Universitas Indonesia

Press

Nadar,F. X.(2009). Pragmatik dan Penelitian Pragmatik. Yogyakarta:

Trosborg, A. (1995). Interlanguage pragmatics: Request, complaints, and apologies. NY: Moutonde Gruyter.

Yule, G. (2006). Pragmatik. Cambridge. Cambridge University Press. 